\title{
FROM PHYTOCHEMISTRY TO METABOLOMICS: EIGHT DECADES OF RESEARCH IN PLANT AND FOOD SCIENCE
}

\section{CARMEN SOCACIU}

\begin{abstract}
Phytochemistry represents a large interdisciplinary research area which apply the chemical knowledge in plant biology, biochemistry and physiology. Since centuries, the technology related to the isolation and characterization of phytochemicals (plant secondary metabolites) developed gradually towards a holistic approach of omics' technology, as part of the "systems biology" concept. This review underlines the scientific progress during the last eight decades, from "classical" phytochemistry to metabolomics, applied on plants and food and reflects not only the role of phytochemicals as key-molecules with essential roles in plants and with great benefits on animal and human health, but also their involvement in plant chemotaxonomy, food technology and authenticity. First, a selection of the major groups of phytochemicals and their main bioresources. The metabolomic technology is presented, as a high-throughput analytical platform to identify, by untargeted or targeted techniques, the fingerprint or key metabolites of a specific pathway in plants or for authentication of a food matrix. Updated literature data are presented, including a summary of eight decades of achievements of the research group related to Chemistry and Biochemistry of Natural Products at the University of Agricultural Sciences and Veterinary Medicine Cluj-Napoca, celebrating now 150 years of existence.
\end{abstract}

Keywords: Phytochemistry, Metabolomics, Analytical platform

\section{INTRODUCTION}

\section{Phytochemicals}

Since centuries, plants were studied as huge reservoir of valuable, small molecules, named phytochemicals. Phytochemistry was defined as being the study of these chemicals in plants and includes their isolation,

\footnotetext{
a University of Agricultural Sciences and Veterinary Medicine, 3-5 Manastur Street, 400372 Cluj-Napoca, Romania, e-mail: carmen.socaciu@usamvcluj.ro
} 
structural analysis, biosynthesis and their functions in plants, animals and humans, as reported by Lind since 1757, Eijkman in 1929 or Szent-Györgyi in 1939, recently cited [1]. Nearly 400,000 flowering plants have been classified so far, only around $5 \%$ being used for medicinal purposes, and only a minority were studied in detail with regard to the chemical composition and biological effects.

The Dictionary of Natural Products contains around 160,000 chemical entities isolated from plants and microorganisms [2]. Medicinal plants have always been used since ancient times to treat diseases, but the knowledge about active components of herbal preparations remained fragmentary since the biosynthetic pathways of many secondary metabolites of pharmacological importance have been elucidated only in a few species, while their chemodiversity remained largely unexplored [3, 4].

Phytochemistry adopts a phylogenetic approach and can be considered as an independent sub-field of botany or chemistry which analyses plants, identify and describe the structures of the large number of small molecules (secondary metabolites) produced by plants for their reproduction, insects' attraction and defense against pathogens. While primary metabolites (carbohydrates, proteins and amino acids, lipids) are related to the nutritional quality of plants and food, phytochemicals are "non-nutrients" but highly bioactive compounds with positive or negative effects on human health. Such secondary metabolites display a large structural diversity, reflecting the higher plants phenotype and adaptations to the various ecological environments [5] their biosynthesis and functions in plants being complemented by their actions, which determined the development of phytopharmacy and phytomedicine, providing the evidence of their health benefits [6].

There are three major groups of phytochemicals: phenolics (representing aprox. $45 \%$ ), terpenoids and steroids (27\%), alkaloids (18\%) and other organosulfur or organo-nitrogen derivatives. Phenolics are water soluble compounds found in different plant and food sources while terpenes and terpenoids are lipophilic groups of major phytochemicals, as presented in Table 1. Alkaloids and sulfur- or nitrogen-containing phytochemicals are also included. 
Table 1. Major groups of phytochemicals (classes, sub-classes, molecular species) and their main biosources

\begin{tabular}{|c|c|c|c|c|}
\hline Group & Class & Sub-class & Molecular species & Main bioresources \\
\hline \multirow[t]{14}{*}{ Phenolics } & \multirow[t]{2}{*}{$\begin{array}{l}\text { Phenolic } \\
\text { acids }\end{array}$} & $\begin{array}{l}\text { Hydro } \\
\text { benzoic acids }\end{array}$ & $\begin{array}{l}\text { gallic acid, ellagic acid, } \\
\text { vanillic acid }\end{array}$ & $\begin{array}{l}\text { grape seed, raspberries, } \\
\text { vanilla, tea, blackberries, } \\
\text { pomegranate }\end{array}$ \\
\hline & & $\begin{array}{l}\text { Hydroxy } \\
\text { cinnamic acids }\end{array}$ & $\begin{array}{l}\text { ferulic acid, o- and } \\
\text { p-coumaric acid, caffeic } \\
\text { acid, sinapic acid }\end{array}$ & $\begin{array}{l}\text { wheat bran, cinnamon, } \\
\text { coffee, kiwi fruit, plums, } \\
\text { blueberries }\end{array}$ \\
\hline & \multirow[t]{8}{*}{ Flavonoids } & Flavonols & quercetin, kaempferol & $\begin{array}{l}\text { onions, kale, leeks, } \\
\text { broccoli, buckwheat, red } \\
\text { grapes, tea, apples }\end{array}$ \\
\hline & & Flavones & apigenin, luteolin & $\begin{array}{l}\text { celery, herbs, parsley, } \\
\text { chamomile, rooibos tea, } \\
\text { capsicum pepper }\end{array}$ \\
\hline & & Isoflavones & $\begin{array}{l}\text { genistein, daidzein, } \\
\text { glycitein }\end{array}$ & $\begin{array}{l}\text { soya, beans, chick peas, } \\
\text { alfalfa, peanuts }\end{array}$ \\
\hline & & Flavanones & naringenin, hesperitin & citrus fruits \\
\hline & & $\begin{array}{l}\text { Anthocyanidins } \\
\text { and } \\
\text { anthocyanins }\end{array}$ & $\begin{array}{l}\text { cyanidin, delphinidin, } \\
\text { malvidin, pelargonidin, } \\
\text { peonidin, petunidin }\end{array}$ & $\begin{array}{l}\text { red grapes, blueberries, } \\
\text { cherries, strawberries, } \\
\text { blackberries, } \\
\text { raspberries, tea }\end{array}$ \\
\hline & & Flavan-3-ols & $\begin{array}{l}\text { catechins, epicatechin, } \\
\text { epigallocatechin gallate }\end{array}$ & $\begin{array}{l}\text { green tea, chocolate, } \\
\text { grape seeds }\end{array}$ \\
\hline & & Flavanolols & silymarin, silibinin & $\begin{array}{l}\text { milk thistle, red onions, } \\
\text { artichoke }\end{array}$ \\
\hline & & $\begin{array}{l}\text { Dihydrochal- } \\
\text { cones }\end{array}$ & phloridzin, aspalathin & apples, rooibos tea \\
\hline & \multirow[t]{4}{*}{$\begin{array}{l}\text { Non-flavonoid } \\
\text { polyphenols }\end{array}$} & Tannins & Condensed cathechins & $\begin{array}{l}\text { cereals, fruits, berries, } \\
\text { beans, red wine, cocoa }\end{array}$ \\
\hline & & Curcuminoids & curcumin & Turmeric root \\
\hline & & Stilbenes & $\begin{array}{l}\text { cinnamic acid, } \\
\text { resveratrol }\end{array}$ & $\begin{array}{l}\text { grapes, wine, } \\
\text { blueberries, raspberries }\end{array}$ \\
\hline & & Lignans & $\begin{array}{l}\text { secoisolarici-resinol, } \\
\text { sesamin }\end{array}$ & $\begin{array}{l}\text { grains, flaxseed, sesame } \\
\text { seeds }\end{array}$ \\
\hline \multirow[t]{4}{*}{ Terpenoids } & Monoterpenes & C10 & $\begin{array}{l}\text { geraniol, limonen, citral, } \\
\text { myrcen, menthol }\end{array}$ & $\begin{array}{l}\text { lemon, orange, mentae } \\
\text { leaves, hops }\end{array}$ \\
\hline & Sesquiterpenes & C15 & farnesol, cadinen & cassie, acacia, juniperus \\
\hline & Diterpenes & $\mathrm{C} 20$ & $\begin{array}{l}\text { cafestol, phytol, } \\
\text { vitamin A } \\
\text { ginkgolide }\end{array}$ & $\begin{array}{l}\text { green leaves, vegetable } \\
\text { oils } \\
\text { Ginkgo biloba }\end{array}$ \\
\hline & Triterpenes & C30 & $\begin{array}{l}\text { squalene, ursolic acid, } \\
\text { betuline and betulinic } \\
\text { acid }\end{array}$ & $\begin{array}{l}\text { birch, apples, } \\
\text { cranberries, peppermint, } \\
\text { oregano, thyme }\end{array}$ \\
\hline
\end{tabular}




\begin{tabular}{|c|c|c|c|c|}
\hline Group & Class & Sub-class & Molecular species & Main bioresources \\
\hline & & & $\begin{array}{l}\text { Phytosterols (sitosterol, } \\
\text { sitosterol, stigmasterol) }\end{array}$ & $\begin{array}{l}\text { Vegetable oils, cereal } \\
\text { grains, nuts, shoots, } \\
\text { legumes }\end{array}$ \\
\hline & Tetraterpenes & C40 & $\begin{array}{l}\text { Carotenes } \\
\text { cryptoxanthin } \\
\text { lycopene } \\
\text { lutein } \\
\text { zeaxanthin } \\
\text { astaxanthin }\end{array}$ & $\begin{array}{l}\text { sweet potato, carrots, } \\
\text { pumpkin, } \\
\text { tomatoes watermelon, } \\
\text { guava, papaya } \\
\text { corn, eggs, kale, } \\
\text { spinach, red pepper, } \\
\text { pumpkin, oranges, } \\
\text { rhubarb, plum, mango, } \\
\text { papaya) } \\
\text { salmon, shrimp }\end{array}$ \\
\hline & & Saponins & & chickpeas, soya beans \\
\hline & & Perillyl Alcohols & & $\begin{array}{l}\text { cherries, caraway seeds, } \\
\text { mint }\end{array}$ \\
\hline \multirow[t]{4}{*}{ Alkaloids } & $\begin{array}{l}\text { Free alkaloids N- } \\
\text { heterocycle }\end{array}$ & & $\begin{array}{l}\text { atropine, nicotine, } \\
\text { morphine, cocaine }\end{array}$ & $\begin{array}{l}\text { Atropa belladonna, } \\
\text { tabac, coke leaves, } \\
\text { poppyseed }\end{array}$ \\
\hline & $\begin{array}{l}\text { Polyamine } \\
\text { alkaloids }\end{array}$ & & palustrine, verbasceine & Horsetail, soy bean \\
\hline & Pseudoalkaloids & & $\begin{array}{l}\text { caffeine, solanidine, } \\
\text { aconitine }\end{array}$ & $\begin{array}{l}\text { Coffee, Potatoes, } \\
\text { tomatoes, Aconite }\end{array}$ \\
\hline & Protoalkaloids & & ephedrine, mescaline & $\begin{array}{l}\text { Aconite, Bear's-Foot, } \\
\text { Peyote }\end{array}$ \\
\hline \multirow[t]{6}{*}{$\begin{array}{l}\text { Sulfur- and } \\
\text { non-Sulfur }\end{array}$} & Glucosinolates & & $\begin{array}{l}\text { Isothiocyanates } \\
\text { (sulforaphane) and } \\
\text { dithiolthiones }\end{array}$ & $\begin{array}{l}\text { Cruciferous vegetables e } \\
\text { g. broccoli, Brussels } \\
\text { sprouts, cauliflower, } \\
\text { cabbage, radish, } \\
\text { mustard }\end{array}$ \\
\hline & Allylic sulfides & & $\begin{array}{l}\text { Allicin and S-allyl } \\
\text { cysteine }\end{array}$ & garlic, leeks, onions \\
\hline & Indoles & & Indole-3-carbinol & $\begin{array}{l}\text { Broccoli, Brussels } \\
\text { sprouts }\end{array}$ \\
\hline & Betaines & & Betalaine & Beetroot \\
\hline & Chlorophylls & & Chlorophyll a and b & Green plant tissues \\
\hline & $\begin{array}{l}\text { Purgent } \\
\text { compounds }\end{array}$ & & Capsaicin, piperine & Chilli, black peppers \\
\hline
\end{tabular}

\section{METABOLOMICS - AN EMERGING ANALYTICAL PLATFORM}

Metabolomics, the newest, "apogee of omics' technology", is defined as a holistic qualitative and quantitative analysis of all small metabolites (of less than 1500 Daltons) found in a biological system $[7,8]$. The term "metabolomics" 
was mentioned for the first time in 1998 and developed tremendously as a valuable tool for advancing our understanding of primary and secondary metabolism in plants. It brings a holistic understanding of plant biology [9], as a complementary technology to functional genomics approaches such as transcriptomics and proteomics and contributes to a systems biology approach. Moreover, metabolomics as a post-genomics tool may offer distinct advantages when compared to other '-omics' technologies. (e.g. changes in the transcriptome or proteome do not always correlate to biochemical phenotypes).

Metabolomics technology involve advanced analytical tools that provide high degrees of sensitivity, selectivity and reproducibility are required. State-of-the-art of metabolomics comprises emerging analytical platforms such as gas chromatography and liquid chromatography-mass spectrometrybased techniques (GC-MS and HPLC-MS) and nuclear magnetic resonance (NMR) spectroscopy, Raman and FTIR spectroscopy. Each approach has its own advantages and disadvantages [10-13].

A Web of Science recent search, using the terms "metabolomics" or "metabonomics" found around 8800 publications. Such data provides high level information regarding the key-biomarkers for a specific plant or food, novel chemotaxonomic markers of biodiversity, plant-based drug discovery, food authenticity and traceability, as well the impacts of environmental stress or processing technology.

There are three different approaches to metabolomics that support the compound discovery efforts: targeted metabolomics, untargeted metabolomics and a hybrid technique of targeted-untargeted metabolomics.

Targeted metabolomics is a term used for the identification and quantification of one or more targeted molecules in a biological sample. Targeted analysis uses standards and/or spectroscopic data libraries, often in conjunction with other "omics" technologies in order to answer a specific research questions. It resembles to traditional phytochemical analysis which quantify specific molecules or classes of metabolites by optimizing their extraction, separation and detection methods.

The untargeted metabolomics is an unsupervised, data-driven approach, a process generating data sets which represents the whole chemical spectrum of a biological sample without bias, with predictive power. The untargeted analysis have a great potential in chemometric fingerprinting, compound and pathway discovery and hypothesis generation, but standardization is difficult and the potential for false discovery is high.

Targeted-untargeted metabolomics is a hybrid of analytical approach which combines technologies (chromatography, spectrometry) using available databases or other "omics" to target specific metabolites. Untargeted data sets are mined for known compounds from different species or tissues or 
food matrices. The discovery of new metabolites and putative pathways is possible by these technologies, finding relationships between molecules in the data sets.

Metabolomics uses, beside advanced analytical technologies, subsequent multivariate data analyses and updated biostatistics tools (e.g. Profile Analysis, Metaboanalyst) [14]. Recently, available databases of metabolome and metabolic biomarkers (Lipid Gateway, Phenol Explorer, KEGG) became also sine-qua-non tools for adequate interpretation of biological significance [15]. Also, the Dr. Duke's Phytochemical and Ethnobotanical database facilitates in-depth searches of plants, chemicals, bioactivity and ethnobotany [16].

\section{PLANT AND FOOD METABOLOMICS}

\section{Plant phenotyping and food authentication}

Plant metabolomics was defined as a "large scale phytochemistry" [17], a "new frontier" in phytochemical analysis [18], a "missing link" in functional genomics [19, 20]. It provides an integrative view of endogenous metabolic patterns during plant growth, development and senescence but also responses to genetic events, environment and disease, gathering new information about the plant secondary metabolism. It covers new, interdisciplinary topics related to plant science, from chemotaxonomy, stress and biotic interactions, systemic pathogen resistance, induced resistance to diseases, plant and food authentication by specific biomarkers, biomarkers for biomedical applications (19, 21-23]. The metabolite profiling is also an aid to metabolic engineering in plants [24].

This technology differs from the classical phytochemical analysis in various fundamental aspects, being a holistic, data-driven approach with predictive power to assess all measurable metabolites without any preconception or pre-selection (as untargeted fingerprinting), possibly followed by targeted metabolite identification and quantitation. The phylogenetic approach of phytochemistry is completed by the performance of 'omics' tools based on advanced analysis, as reviewed recently [25, 26].

Plants have one of the largest metabolome (full set of metabolites), their leaves contain up to 30000 phytochemicals, an arsenal prepared to survive and fight against abiotic and biotic environmental stressors. More than 200000 different secondary metabolites have been isolated, purified, and identified from plants. In the past decade, around 1200 articles have been published describing plant metabolomes. The key factors in using efficiently the plant metabolomics data are the experimental design, authentic standard availability, extract standardization and statistical analysis. 
Since abiotic and biotic stresses are the main reasons of substantial crop yield losses worldwide, recent researches were devoted to the mechanisms of plant interactions with the environment and the resistance to stress, especially using metabolomics technology based on mass spectrometry [27]. Among omics approaches, the metabolomics is the most complex and has received inadequate attention in crop science, particularly for trait mapping and plant selections [28]. An overview of the fundamental analytical technologies and subsequent multivariate data analyses involved in plant metabolomics was recently published [20]. The diverse omics platforms have great potential in improving the current understanding of important traits, enabling to develop new strategies for plant improvement. For the continued development of plant metabolomics, at least three objectives still need to be achieved: improvements in the elucidation of plant metabolome, comparisons of the results found in different laboratories and experiments, followed by the integration of plant metabolomics data with other functional genomics.

The plant metabolomic analysis developed rapidly in line with the new analytical tools for chemical separations (gas and liquid chromatography, capllary electrophoresis) and detection for molecular identification (mass spectrometry and NMR spectroscopy) which emerged the last decades, generating valuable metabolite databases [29], as presented above.

The general application of metabolomics in food science and nutrition has been also reviewed [30,31] underlying the importance of improvements in food analytical chemistry, such as high-resolution mass spectrometry, NMR and advanced statistical techniques to process the large data sets [32, 33]. Plant and food metabolomics has improved our capacity to analyse the overall metabolome as well as helping to perform pathway analysis and metabolite identification [11,13]. Metabolomics tools are only now being used to identify different food components but also the food born derivatives, such as flavours during food processing. Recently, there were characterized the characteristics of the different groups of aroma-related metabolites and their relevant chemical and sensorial characteristics [33], including Maillard reaction pathways. Small phytochemical metabolites play a central role in food quality as they are coloured, fragrant or bioactive, contributing to nutritional value and to positive or negative sensory attributes (e.g. off-flavours). More than 20,000 compounds are identified in different foods (http://www.Foodb.ca). To understand the relationship between food quality and processing, a complete analysis of the metabolites present in a food sample is still needed [34]. Mass spectrometry (MS)-based techniques are the most widely used in food science either for volatile or non volatile, polar or unipolar molecules [35]. 
Food adulteration, mislabeling and fraud, is a worldwide growing concern. Current challenges associated with food authentication are influenced by the geographic origin, breed/variety identification, plant/animal production technology, food processing, etc. Accurate and reliable analytical methods are applied nowadays to monitor and control food authenticity and to guarantee correct and accurate labeling of foodstuffs, assuring that the components included in a food product are of the nature and quality declared by the seller. Omics' based technologies circumvent the limitations of traditional methodologies, being developed for the authentication of a wide range of food commodities. Recently it was reviewed the updated literature, since 2015, which applied omics-based technologies and especially metabolomics, for food authentication [36].

\section{TRADITION AND MODERNITY}

\section{Years of Research at USAMV in Cluj-Napoca, Romania}

The research group on "Chemistry and Biochemistry of Natural Compounds" was created since 80 years, at the former Institute of Agronomy in Cluj, known today as University of Agricultural Sciences and Veterinary Medicine, which celebrates this year 150 years of existence. The mentor of this group, professor Cornel Bodea (member of Romanian Academy and director of the Institute of Chemistry in Cluj) have had major contributions to the development of Phytochemistry in Romania, leading the most prominent group of Plant Science research in Romania, especially focused on secondary metabolites (carotenoid pigments), their biosynthesis, isolation and characterization from different bioresources, as well the beneficial effects on animals and humans. The scientific performance of this group, especially the last 5 decades is revealed by many international collaborations and publications in books, international journals. A prove of its international recognition was the organization, in 1972 of the $3^{\text {rd }}$ International Carotenoid Symposium in Cluj. The scientific performance was continued by the followers Prof. G. Neamţu, prof. V. Tămaş and their collaborators, some of the most relevant publications being mentioned in Table 2.

The last 3 decades, another significant progress was noticed in this group, in-line to the diversification of phytochemistry areas and development of omics' technologies, as well due to the improvement of analytical facilities and formation of young scientists, approaching the plant and food metabolomics technology. Secondary metabolites, especially carotenoids, tocopherols, phytosterols, fatty acids, terpenoids, different polyphenols (from 
phenolic acids to flavonoids, catechins and anthocyanins), but also terpenoids, glucosinolates from different plant sources enlarged the scientific areas of interest, being focused on the improvement of extraction procedures, separation by different chromatographic tools, isolation and characterization by different spectrometry tools, evaluation of their antioxidant/antitumor effects. Advanced biostatistics was developed for the proper classification (plant chemotaxonomy), confirmation of food authenticity or fraud identification. Table 2 reviews the most significant results, published in many international impact publications (more than 220, according to Web of Science) which prove the scientific performance reached nowadays. More than $40 \mathrm{PhD}$ students were trained and involved in different projects and experiments related to Phytochemistry, Plant and Food metabolomics, including applications bio(nano)technology and in biomedical areas. The progress of this group' knowledge and expertise was significantly due to the performant metabolomic platform (HPLC-DAD-MS, GC-MS, Raman and FTIR Spectrometry) and advanced biostatistics/bioinformatics tools (multivariate combined with univariate data analyses) in the context of systems biology concept.

The previous and present studies, as well the results on applying omics'techniques are presented below, showing their impact on the new, emerging research areas such as bioeconomy, food industry, functional food and nutrition, phytomedicine [37].

Table 2. Relevant scientific areas and publications realized by the research group on Natural Product Chemistry from USAMV Cluj-Napoca

\begin{tabular}{|l|l|}
\hline \multirow{3}{*}{$\begin{array}{l}\text { Reviews } \\
\text { and books }\end{array}$} & Topics /Titles [reference] \\
\cline { 2 - 2 } & Treatise de Plant Biochemistry ( vol I-VI) [38] \\
\cline { 2 - 2 } & Rarotenod pigments and metabolites [39] \\
\cline { 2 - 2 } & Fecent advances in the chemistry of phenothiazines [40] \\
\hline & $\begin{array}{l}\text { Food Chemistry [41] } \\
\text { Bolecular composition of carotenoid-lipo-protein structures of Seabuckthorn }\end{array}$ \\
\cline { 2 - 2 } & Xanthophyll Esters in Fruits and Vegetables [43] \\
\hline & Food Colorants: Chemical And Functional Properties [ 44] \\
\hline & Instruments to analyse food colors [ 45] \\
\cline { 2 - 2 } & $\begin{array}{l}\text { Advances in natural food colorant chemistry. Part 1. Current technologies } \\
\text { applied for pigments' extraction [46 ] }\end{array}$ \\
\cline { 2 - 2 } & $\begin{array}{l}\text { Lipoxygenase-Quercetin Interaction: A Kinetic Study Through Biochemical and } \\
\text { Spectroscopy Approaches [47 ] }\end{array}$ \\
\cline { 2 - 2 } & Phytochemical Antioxidants [ 48] \\
\hline
\end{tabular}




\begin{tabular}{|c|c|}
\hline & Topics /Titles [reference] \\
\hline & $\begin{array}{l}\text { Antioxidant phytochemicals: Chemical characterization, functions and actions } \\
\text { [ 49] }\end{array}$ \\
\hline & Antioxidant Activity of European Mistletoe [50] \\
\hline & Anthocyanins-Smart Molecules for Cancer Prevention [51] \\
\hline & $\begin{array}{l}\text { Plant and food metabolomics in the post genomic era: concepts, } \\
\text { methodologies and applications [52] }\end{array}$ \\
\hline & Plants and natural compounds with antidiabetic action [ 53] \\
\hline & $\begin{array}{l}\text { Pharmacological Benefits of Herbal Formulations in the Management of } \\
\text { Psoriasis vulgaris [ 54] }\end{array}$ \\
\hline & Plant metabolomics versus phytochemistry. What makes the difference? [55] \\
\hline & Plant metabolomics beyond genomics [ 56$]$ \\
\hline & $\begin{array}{l}\text { Screening of bioactive compounds synthesized by microalgae: a progress } \\
\text { overview on extraction and chemical analysis [57] }\end{array}$ \\
\hline & Bioactive ingredients from microalgae: food and feed application [58] \\
\hline & $\begin{array}{l}\text { Complementary advanced techniques applied for plant and food } \\
\text { authentication [59] }\end{array}$ \\
\hline & $\begin{array}{l}\text { Challenges and impact of high-throughput targeted and untargeted plant/food } \\
\text { medical metabolomics using UPLC-MS and FTIR technologies [60] }\end{array}$ \\
\hline & $\begin{array}{l}\text { Four Steps Metabolomic Characterization of Pigments as Biomarkers of Food } \\
\text { Quality and Authenticity [61] }\end{array}$ \\
\hline & $\begin{array}{l}\text { Plant and food metabolomics: fingerprints of phytochemicals as authenticity } \\
\text { markers of medicinal plant extracts and functional food [62] }\end{array}$ \\
\hline & $\begin{array}{l}\text { Applied metabolomics in Romania: from plant taxonomy to food quality, } \\
\text { authenticity and traceability [63] }\end{array}$ \\
\hline & Advances in Distilled Beverages Authenticity and Quality Testing [ 64] \\
\hline & $\begin{array}{l}\begin{array}{l}\text { Foodomics: an advanced technology to integrate Food Analysis in the systems' } \\
\text { biology approach [65] }\end{array} \\
\text { (a) }\end{array}$ \\
\hline \multirow[t]{11}{*}{$\begin{array}{l}\text { Phytochemic } \\
\text { al analysis }\end{array}$} & $\begin{array}{l}\text { Polar lipids and fatty acid distribution in carotenoprotein complexes extracted } \\
\text { from Sea Buckthorn fruit [66] }\end{array}$ \\
\hline & Qualitative analysis of phytosterols from different extracts [67] \\
\hline & Structure of the carotenoid physoxanthin [68] \\
\hline & Cyclization reactions of carotenoids [69] \\
\hline & Enzymatic hydrolysis of zeaxanthin esters from Physalis Alkekengi [70] \\
\hline & $\begin{array}{l}\text { Gas-Chromatographic Analysis of Major Volatile Compounds Found in } \\
\text { Traditional Fruit Brandies from Transylvania [71] }\end{array}$ \\
\hline & $\begin{array}{l}\text { Polyphenolic Content and Antioxidant Activities of Some Wild and Cultivated } \\
\text { Blueberries from Romania [72] }\end{array}$ \\
\hline & $\begin{array}{l}\text { Fatty acid and phytosterol contents of some Romanian wild and cultivated } \\
\text { berry pomaces [73] }\end{array}$ \\
\hline & $\begin{array}{l}\text { Evaluation of Betulin and Betulinic Acid Content in Birch Bark from Different } \\
\text { Forestry Areas of Western Carpathians [74] }\end{array}$ \\
\hline & $\begin{array}{l}\text { Carotenoid composition of Rosa canina fruits determined by thin-layer } \\
\text { chromatography and high-performance liquid chromatography [75] }\end{array}$ \\
\hline & $\begin{array}{l}\text { Carotenoids, tocopherols and antioxidant activity of lipophilic extracts from sea } \\
\text { buckthorn berries (Hippophae rhamnoides) and apricots (Prunus armeniaca) } \\
{[76]}\end{array}$ \\
\hline
\end{tabular}




\begin{tabular}{|c|c|}
\hline & Topics /Titles [reference] \\
\hline & $\begin{array}{l}\text { Combined HPLC/UV-Vis/FTIR fingerprints of antioxidant phytochemicals as } \\
\text { functional food authenticity, quality and functionality markers [77] }\end{array}$ \\
\hline & $\begin{array}{l}\text { Lipid Classes and Fatty Acid Regiodistribution in Triacylglycerols of Seed Oils } \\
\text { of Two SambucusSpecies (S. nigra L. and S. ebulus L.) [78] }\end{array}$ \\
\hline & $\begin{array}{l}\text { Total and individual carotenoids and phenolic acids content in fresh, refriger- } \\
\text { ated and processed spinach (Spinacia oleracea I.) [79] }\end{array}$ \\
\hline \multirow{21}{*}{$\begin{array}{l}\text { Phytochemic } \\
\text { als activity } \\
\text { and effects }\end{array}$} & Antioxidant/prooxidant activity of a polyphenolic grape seed extract [80] \\
\hline & $\begin{array}{l}\text { Hydrophilic and Lipophilic Antioxidant Activities of Mistletoe (Viscum album) } \\
\text { [81] }\end{array}$ \\
\hline & $\begin{array}{l}\text { Competitive carotenoid and cholesterol incorporation into liposomes:effect on } \\
\text { membrane phase transition, fluidity, polarity and anisotropy [82] }\end{array}$ \\
\hline & Carotenoids in DPPC vesicles: membrane dynamics [83] \\
\hline & $\begin{array}{l}\text { Carotenoid incorporation into biological membranes from artificial carriers: } \\
\text { liposomes and beta-cyclodextrins [84] }\end{array}$ \\
\hline & Incorporation of carotenoid esters in liposomes [85] \\
\hline & $\begin{array}{l}\text { HPLC analysis of carotenoids in four varieties of Calendula Officinalis } L \text {. } \\
\text { Flowers [86] }\end{array}$ \\
\hline & $\begin{array}{l}\text { Chromatographic analysis (HPLC, GC) of Carotenol Fatty Acids Esters in } \\
\text { Physalis alkekengi and Hippophae rhamnoides [87] }\end{array}$ \\
\hline & $\begin{array}{l}\text { Iron chelation properties of phenolic acids bearing catechol and galloyl groups } \\
\text { [88] }\end{array}$ \\
\hline & $\begin{array}{l}\text { Antioxidant Activity Of Flavanols From Different Romanian Grape Seed Extracts } \\
\text { [89] }\end{array}$ \\
\hline & $\begin{array}{l}\text { Lactic Acid Production by Lactobacillus paracasei } 168 \text { in Discontinuous } \\
\text { Fermentation Using Lucerne Green Juice as Nutrient Substitute [90] }\end{array}$ \\
\hline & $\begin{array}{l}\text { Selenium enriched green tea coencapsulated with } B \text {. infantis or } B \text {. breve in } \\
\text { chitosan coated alginate capsules improves survival of bacteria in simulated } \\
\text { gastro-intestinal and refrigerated conditions [91] }\end{array}$ \\
\hline & $\begin{array}{l}\text { Catechin-rich green tea extract modulates the oxidative status of human retinal } \\
\text { pigment epithelial cells [92] }\end{array}$ \\
\hline & Inhibitory Effects Of Isoflavones on Soybean Lipoxygenase-1 Activity [93] \\
\hline & $\begin{array}{l}\text { Comparative study about antioxidant activities of Viscum album from different, } \\
\text { host trees, harvested in different seasons [94] }\end{array}$ \\
\hline & $\begin{array}{l}\text { Xanthophylls protect against induced oxidation in cultured human retinal } \\
\text { pigment epithelial cells [95] }\end{array}$ \\
\hline & $\begin{array}{l}\text { Evaluation of Hydrolytic Activity of Different Pectinases on Sugar Beet (Beta } \\
\text { vulgaris) Substrate Using FT-MIR Spectroscopy [96] }\end{array}$ \\
\hline & $\begin{array}{l}\text { Antioxidant Effect of Trans-Resveratrol in Cultured Human Retinal Pigment } \\
\text { Epithelial Cells [97] }\end{array}$ \\
\hline & $\begin{array}{l}\text { Antioxidant activities of chokeberry extracts and the cytotoxic action of their } \\
\text { anthocyanin fraction on HeLa human cervical tumor cells [98] }\end{array}$ \\
\hline & $\begin{array}{l}\text { Green tea increases the survival yield of Bifidobacteria in simulated } \\
\text { gastrointestinal environment and during refrigerated conditions [99] }\end{array}$ \\
\hline & $\begin{array}{l}\text { Anthocyanin determination in blueberry extracts from various cultivars and } \\
\text { their antiproliferative and apoptotic properties in B16-F10 metastatic murine } \\
\text { melanoma [100] }\end{array}$ \\
\hline
\end{tabular}




\begin{tabular}{|c|c|}
\hline & Topics /Titles [reference] \\
\hline & $\begin{array}{l}\text { Green synthesis of gold nanoparticles by Allium sativum extract and their } \\
\text { assessment as SERS substrate [101] } \\
\text { Selenium enriched green tea increase stability of Lactobacillus casei and } \\
\text { Lactobacillus plantarum in chitosan coated alginate microcapsules during } \\
\text { exposure to simulated gastrointestinal conditions [102] }\end{array}$ \\
\hline & $\begin{array}{l}\text { Structure and dose-related stability and antioxidant activity of catechins in } \\
\text { abiotic vs cell environments: HPLC fingerprint and cellular markers [103] }\end{array}$ \\
\hline & $\begin{array}{l}\text { Antiproliferative and antioxidant properties of anthocyanin rich extracts from } \\
\text { blueberry and blackcurrant juice [104] }\end{array}$ \\
\hline & $\begin{array}{l}\text { Chokeberry Anthocyanin Extract as Pancreatic } \beta \text {-Cell Protectors in Two } \\
\text { Models of Induced Oxidative Stress [105] }\end{array}$ \\
\hline & $\begin{array}{l}\text { Effects of solid-state fermentation with two filamentous fungi on the total } \\
\text { phenolic contents, flavonoids, antioxidant activities and lipid fractions of plum } \\
\text { fruit (Prunus domestica) by-products [106] }\end{array}$ \\
\hline & $\begin{array}{l}\text { Melanoma inhibition by anthocyanins is associated with the reduction of } \\
\text { oxidative stress biomarkers and changes in mitochondrial membrane potential } \\
{[107]}\end{array}$ \\
\hline & $\begin{array}{l}\text { Thermal Stability Study of the Grape Seeds Extracts in the Aqueous Solutions } \\
\text { [108] }\end{array}$ \\
\hline $\begin{array}{l}\text { Plant } \\
\text { metabolom- }\end{array}$ & $\begin{array}{l}\text { HPLC separation systems of flavonoids from several medicinal plants buds } \\
\text { [109] }\end{array}$ \\
\hline & $\begin{array}{l}\text { HPLC analysis coupled with diode array detector used in determination of } \\
\text { isoflavone aglycones from different Romanian varieties of soybeans [110] }\end{array}$ \\
\hline & $\begin{array}{l}\text { Composition in polyphenols and stability of the aqueous grape seed extract } \\
\text { from the Romanian variety Merlot Recas [111] }\end{array}$ \\
\hline & $\begin{array}{l}\text { Comparative fingerprint and extraction yield of medicinal herb phenolics with } \\
\text { hepatoprotective potential [112] }\end{array}$ \\
\hline & $\begin{array}{l}\text { Patterns of carotenoid pigments extracted from two orange peel wastes } \\
\text { (Valencia \& Navel var.) [113] }\end{array}$ \\
\hline & $\begin{array}{l}\text { HPLC Fingerprint of Bioactive Compounds and Antioxidant Activities of Viscum } \\
\text { album from Different Host Trees [114] }\end{array}$ \\
\hline & $\begin{array}{l}\text { Chemometric discrimination of different tomato cultivars based on their volatile } \\
\text { fingerprint in relation to lycopene and total phenolics content [115] }\end{array}$ \\
\hline & $\begin{array}{l}\text { In-tube extraction and GC-MS analysis of volatile components from wild and } \\
\text { cultivated Sea Buckthorn (Hippophae rhamnoides L. ssp Carpatica) Berry } \\
\text { Varieties and Juice [116] }\end{array}$ \\
\hline & $\begin{array}{l}\text { Glucosinolates profile and antioxidant capacity of Romanian Brassica } \\
\text { vegetables obtained by organic and conventional agricultural practices [117] }\end{array}$ \\
\hline & $\begin{array}{l}\text { Carotenoid composition of berries and leaves from six Romanian Sea } \\
\text { Buckthorn (Hippophae rhamnoides L.) varieties [118] }\end{array}$ \\
\hline & $\begin{array}{l}\text { Fingerprint and Quantification of Phenolic and Flavonoid Composition of } \\
\text { Aqueous Leaf Extracts of Cornus mas and Crataegus monogyna [119] }\end{array}$ \\
\hline & $\begin{array}{l}\text { UHPLC/PDA-ESI/MS Analysis of the Main Berry and Leaf Flavonol Glycosides } \\
\text { from Different Carpathian Hippophae rhamnoides L. Varieties [120] }\end{array}$ \\
\hline & $\begin{array}{l}\text { Untargeted metabolomics for Sea Buckthorn (Hippophae rhamnoides } \\
\text { ssp.carpatica) berries and leaves: Fourier Transform Infrared Spectroscopy as } \\
\text { a rapid approach for discrimination [121] }\end{array}$ \\
\hline
\end{tabular}






\section{CONCLUSION}

The scientific progress registered in phytochemistry and plant or food metabolomics, since eight decades was mainly due to the added-value knowledge and improvements of analytical platforms (from Infrared and 
Raman spectrometry as rapid fingerprinting spectrometry techiques, gas- or liquid chromatography as main advanced separation techniques, coupled with mass-spectrometry or magnetic resonance), new biostatistics software and databases as well formation of a new generation of scientists trained in these emerging areas. This review shows not only the progress at international scale, related to plant and food phytochemistry and metabolomics, but reveals the Romanian contributions and significant achievements of the research group from the Departments and Research Centers related to Chemistry and Biochemistry of Natural Products. It is a welcomed occasion to celebrate the remarkable scientific quality brought by a synergic combination of "tradition and modernity" here in Cluj-Napoca, at the University of Agricultural Sciences and Veterinary Medicine which celebrates this year 150 years of existence.

\section{ACKNOWLEDGENENT}

I would like to thank all my former and present collaborators, many of them my previos PhD students, who contributed significantly to the scientific performance of our group in Phytochemistry and Metabolomics research: Adela Pintea, Elena Mudura, Fracisc Dulf, Andreea Bunea, Dan Vodnar, Constantin Bele, Madalina Neacsu, Sanda Andrei, Teodora Coldea, Sonia Socaci, Loredana Leopold, Cristina Coman, Lucian Cuibus, Veronica Chedea, Dumitriţa Rugina, Zoriţa Diaconeasa, Simona Vicaş, Raluca Pop, Oana Pop, Simona Zăvoi, Adina Chiş, Camelia Echim, Floricuta Ranga, Florinela Fetea as well to many collaborators from foreign universities: Hanspeter Pfander from University of Bern, George Britton from Liverpool University, Michel Gleizes from Bordeaux University, Roland Verhe, Mirjana Andjekovics and John Van Camp from Gent University, Horst A. Diehl from Bremen University, Harry Gruppen and Jean Paul Vinken from Wageningen University, Heiki Kallio from Turku University, Panos Kefalas from Mediteranean School Chania. These sciejntists had significant contributions to the training of our researchers in Phytochemistry, incl. Carotenoid Chemistry and Biochemistry, Biophysics, Food Chemistry and Biotechnology.

\section{REFERENCES}

1. R. Wayne; Plant Cell Biology ( $2^{\text {nd }}$ Ed), Ed Elsevier, 2019, 411-423.

2. J. Buckingham; Dictionary of Natural Products. Abingdon: Taylor \& Francis, USA, 1993.

3. F. Scossa; M. Benina; S. Alseekh; Y. Zhang; A.R. Fernie; Planta Med., 2018, 84, 855-887.

4. J. Arnason; R.Mata; J.T.Romeo; Phytochemistry of Medicinal Plants. Springer Science \& Business Media, 2013.

5. E.T. Wurtzel; T.M. Kutchan; Science, 2016, 353, 1232-1236. 
6. M.S. Meskin; Phytochemicals in Nutrition and Health, 2002, CRC Press.

7. O. Fiehn; Plant Mol. Biol., 2002, 48, 155-171.

8. G.J. Patti; O.Yanes; G.Siuzdak; Nature Reviews, 2012, 13, 263-269.

9. U. Roessner; D.A. Dias; (Eds.), Metabolomics Tools for Natural Product Discovery, Methods and Protocols, Humana Press, 2013.

10.W. Weckwerth; Metabolomics: methods-protocols in Methods in molecular biology, Humana Press, 2007.

11.A. Zhang; H. Sun; P. Wang; Y. Han; X. Wang; The Analyst, 2012, 137, 293-300.

12.S.D. Johanningsmeier; G.K. Harris; C.M. Klevorn; Annual Review of Food Science and Technology, 2016, 7, 413-438.

13.D.D. Marshall; R. Powers; (2017). Progress in Nuclear Magnetic Resonance Spectroscopy, 2017, 100, 1-16.

14.C. E. Turi; Jamie Finley; Paul R. Shipley; Susan J. Murch; P. N. Brown; J. Nat. Prod., 2015, 78, 953-966.

15.P. Mendes; Brief. Bioinform., 2002, 3, 134-145.

16.Dr. Duke's Phytochemical and Ethnobotanical Databases, https://phytochem.nal.usda.gov/phytochem/plants.

17.L.W. Sumner; P.Mendes; R.A. Dixon; Phytochemistry, 2003, 62, 817-836.

18.F. Tugizimana; L.Piater; I.Dubery; South Afr. J.Sci., 2013, 109,1-11.

19.R. Hall; M. Beale; O. Fiehn; N.Hardy; L.Sumner; R.Bino; Plant Cell, 2002, 14, $1437-1440$.

20.R.D. Hall (Ed.), Annual Plant Reviews; Wiley-Blackwell Publishing, Oxford, UK, 2011, 43, 448-465.

21.A.R. Fernie; Funct Plant Biol, 2003, 30,111-120.

22.J. Kopka; A. Fernie; W. Weckwerth; Y. Gibon; M. Stitt; Genome Biol., 2004, 5, 109-117.

23.W. Weckwerth (ed.); The Handbook of Plant Metabolomics, Wiley-Blackwell, Guenter Kahl, 2013.

24.R.N. Trethewey; Curr. Opin. Plant Biol., 2004, 7, 196-201.

25.T. Tenenboim; Y. Brotman; Trends in Plant Science, 2016, 21, 781-792.

26.T. Garnatje et al.; Trends in Plant Science, 2017, 22, 187-198.

27.A. Piasecka; P. Kachlick; M. Stobiecki; Int. J. Mol. Sci., 2019, 20, 379-397.

28.R. Kumar; A. Bohra; A.K.Pandey; M.K.Pandey; A.Kumar; Frontiers in Plant Sci., 2017, 8, 1302-1309.

29.C. Deborde; J.X. Fontaine; D. Jacob; A. Botana; V. Nicaise; F. Richard-Forget; S. Lecomte; C. Decourtil; K. Hamade; F. Mesnard; A. Moing; R. Molinié; Metabolomics, 2019, 15, 28-36.

30.D.S. Wishart; Trends Food Sci.Technol., 2008, 19, 482-493.

31.J.M. Cevallos-Cevallos; J.I. Reyes-De-Corcuera; E. Etxeberria; M.D. Danyluk; G.E. Rodrick; Trends Food Sci.Technol, 2009, 20, 557-566.

32.A. Scalbert; L. Brennan; O. Fiehn; T. Hankemeier; B.S. Kristal; B. van Ommen; Metabolomics, 2009, 5, 435-458.

33. J. Rubert; M. Zachariasova; J. Hajslova; Food Additives and Contaminants- Part A Chemistry, Analysis, Control, Exposure and Risk Assessment, 2015, 32, 1685-1708. 
34.U. Thissen; L. Coulier; K.M. Overkamp; J. Jetten; B.J.C. van der Werff; T.Van de Ven; M.J. Van der Werf; Food Quality and Preference, 2011, 22, 499-512.

35.C. Diez-Simon; R. Mumm; R.D. Hall; Metabolomics, 2019, 15, 41-49.

36.K. Bohme; P. Calo-Mata; J. Barros-Velazquez; I. Ortea; Trends Anal. Chem., 2019, 110, 221-234.

37.G. Ulrich-Merzenich; H. Zeitler; D. Jobst; D.Panek; H.Vetter; H.Wagner; Phytomedicine, 2007, 14, 70-82.

38.C. Bodea; Tratat de Biochimie vegetală, Ed.Academiei RSR, vol. I-VI, 1964-1984. 39.G. Neamtu; V.Tămaş; Pigmenţi carotenoidici şi metaboliţi, Ed.Ceres, Bucureşti, 1986.

40.C. Bodea; I. Silberg; Adv. Heterocyclic Chem., 1968, 9, 321-332.

41.C. Socaciu; Chimia Alimentelor, Ed. AcademicPres, Cluj-Napoca, 2017, 126 pag.

42.C. Socaciu; A. Pintea; in Seabuckthorn, A Multipurpose Wonder Plant ed. V. Singh, Indus International, India, 2006, pp. 342-360.

43. A. Bunea; C. Socaciu; A. Pintea; Not. Bot. Horti. Agrobo, 2014, 42, 310-324.

44.C. Socaciu (ed.); Food Colorants: Chemical and Functional Properties, CRC Press-Taylor and Francis Group, New York, 2008, 633 pp.

45.C. Socaciu, H.A. Diehl; Instruments to analyse food colors, in Handbook of Food Analysis Instruments, S. Otles Ed., CRC Press-Taylor and Francis Group, New York, 2009, chapter 1.

46. C. Socaciu; Agrofood Industry Hi-tech, 2009, 20, 43-46.

47.V.S. Chedea; S.I. Vicaş; C. Socaciu; T. Nagaya; H. J. Oduor Ogola; K. Yokota; K. Nishimura; M.Jisaka; Lipoxygenase-Quercetin Interaction: A Kinetic Study Through Biochemical and Spectroscopy Approaches, Biochemical Testing, 2012, InTech Publ, pp. 29.

48.C. Socaciu; in Alimentaţia funcţională cu componente bioactive naturale în sindromul metabolic, Ed. Eurostampa, Timişoara, 2009, pp. 95-127.

49. C. Socaciu; Bull. USAMV-AGR, 2002, 58, 22-29.

50.S.I. Vicas; D. Rugină; C. Socaciu; in Phytochemicals as Nutraceuticals- Global Approaches to Their Role in Nutrition and Health, InTech Publ., 2012, pp. 21.

51.Z. M. Diaconeasa; A. D. Frond; I. Stirbu; D. Rugina; C. Socaciu; AnthocyaninsSmart Molecules for Cancer Prevention, Intech Publ., 2018, chapter 5.

52.C. Socaciu; Bull. USAMV-AGR, 2006, 62, 352-359.

53.C. Coman; O. D. Rugină; C. Socaciu; Not. Bot. Horti. Agrobio., 2012, 40, 314325.

54.A.N. Boca; D. Tataru; A. Buzoianu; C. Pincelli; C. Socaciu; Not. Bot. Horti. Agrobio., 2014, 42, 1-8.

55.C. Socaciu; $1^{\text {st }}$ Int. Congr. Danube Reg. Bot. Gardens, Arad, 7-9.09. 2017.

56.C. Socaciu; Symp. Rom. Acad., University A.I Cuza, laşi, 15.10. 2010.

57.D. Pătraş; C.V. Moraru; C. Socaciu; Screening of bioactive compounds synthesized by microalgae: a progress overview on extraction and chemical analysis, Studia UBB Chemia, 2018, 63, 21-35.

58.D. Pătraş; C.V. Moraru; C. Socaciu; Bull. USAMV -FST, 2019, 76, 1-15.

59.C. Socaciu; F. Ranga; F. Fetea; D. Leopold; F. Dulf; R. Parlog; Czech J. Food Sci., 2009, 27, S70-S75. 
60.C. Socaciu; R. Pop; F.Ranga; F. Fetea; Int. Conf. Rom. Soc. Biochemistry and Molecular Biology, Oradea, 5-6.06.2014.

61.C. Socaciu; $6^{\text {th }}$ Int. Congr. Pigments in Food, Budapest, 2010.

62.C. Socaciu; FI.Ranga; F. Fetea; F.Dulf;, $5^{\text {th }}$ Int. Conf. Plant Metabolomics, Yokohama, Japan, 2008.

63.C.Socaciu; FI.Ranga; F. Fetea; Metabomeeting, Lyon, 2008.

64.T. E. Coldea; E. Mudura; C. Socaciu; Advances in Distilled Beverages Authenticity and Quality Testing, InTechopen Publ. 2017, chapter 6.

65.C. Socaciu; C. Moraru; D. Patras 4th North and East Eur. Congr. on Food, Kaunas, 11-13.09. 2017.

66. A. Pintea; A. Marpeau; M. Faye; C. Socaciu; M. Gleizes; Phytochem. Anal., 2001, 12, 293-298.

67.F. Dulf; C. Socaciu; C. Bele; Bull. USAMV-VM, 2005, 61, 388-393.

68.C. Bodea; A.G. Andrewes; G. Borch; S. Liaaen-Jensen; Phytochemistry, 1978, 17, 2037-2045.

69.C.Bodea; Pure Appl. Chem., 1969, 20, 517-527

70.A. Bunea; A. Pintea; S. Andrei; A. Lujerdean; C. Socaciu; Bull. USAMV-Zoo, 2006, $62,282-286$.

71.T.E. Rusu; C. Socaciu; M. Parv; D.C. Vodnar; Not. Bot. Horti. Agrobo., 2011, 39, 109-116.

72.Bunea; D. O. Rugină; A.M. Pintea; Z. Sconţa; C.I. Bunea; C. Socaciu;, Not. Bot. Horti. Agrobio., 2011, 39, 70-76.

73.F. Dulf; S. Andrei; A. Bunea; C. Socaciu; Chem. Papers, 2012, 66, 925-934.

74.L. Holonec; F.Ranga; D. Crainic; A. Truţa; C. Socaciu; Not. Bot. Horti. Agrobio., 2012, 40, 99-105.

75.T. Hodisan; C. Socaciu; I. Ropan; G. Neamtu; J. Pharm. Biomed. Anal., 1997, 25, 256-262.

76.E.A. Pop; Z.M. Diaconeasa; F.Fetea; A. Bunea; F. Dulf; A. Pintea; C.Socaciu; Bull. USAMV-FST, 2015, 72, 169-175.

77.C. Socaciu; S.Drăgan; F.Ranga; F. Fetea; D.Preda; $3^{\text {rd }}$ Int. Conf. Polyphenols and Health, Kyoto, Japan, 2007.

78.F.V. Dulf; I. Oroian; D.C. Vodnar; C. Socaciu; A. Pintea; Molecules, 2013, 18, 11768-11785.

79. A. Bunea; M. Andjelkovic; C. Socaciu; O. Bobis; M. Neacsu; R. Verhé; J. Van Camp; Food Chemistry, 2008, 108, 649-656.

80.V.S. Chedea; C. Braicu; C. Socaciu; Food Chemistry, 2010, 121, 132-139.

81. S. Vicas; J. Prokisch; D. Rugina; C. Socaciu; Not. Bot. Horti. Agrobo., 2009, 37, 112116.

82.C. Socaciu; R. Jessel; H.A. Diehl; Chem. Phys Lipids, 2000, 106, 79-88.

83.C. Socaciu, S. Haertel; H. A. Diehl; Spectrochimica Acta, part A, 1999, 55, 22892297.

84.I. Lancrajan, H. A. Diehl; C. Socaciu; M. Engelke; M. Zorn-Kruppa; Chem. Phys. Lipids, 2001, 112, 1-10.

85.A. Pintea; C. Socaciu; H. A. Diehl; Biophys. Chem., 2005, 118, 7-14. 
86. A. Pintea; C. Bele; S. Andrei; C. Socaciu; Acta Biol. Szegediensis, 2003, 47, 3740.

87. A. Pintea; A. Varga; P. Stepnowski; C. Socaciu; M. Culea; H.A. Diehl; Phytochemical Analysis, 2005, 16, 188-195.

88. M. Andjelkovic; J. Van Camp; B. De Meulenaer; G. Depaemelaere; C. Socaciu; M. Verloo ; R. Verhe; Food Chemistry, 2006, 98, 23-31.

89.D. Rugină; S. Vicaş; C. Momeu; C. Socaciu; Chem. Listy, 2008, 99, 1234-1235.

90.D.C. Vodnar, J. Venus ; R. Schneider; C. Socaciu; Chem. Eng. \& Technol., 2010, 33, 468-474.

91.D.C. Vodnar; C. Socaciu; International J. Food Sci. \& Technol., 2010, 45, 23452351.

92.A. Pintea; D. Rugina; R. Parlog; C. Socaciu; Rom. Biotechnol. Lett., 2010, 15, 4964-4978.

93.S. Vicas; V. Chedea; C.Socaciu; J. Food Biochem., 2011, 35, 613-627.

94.S. Vicaş; D. Rugina; C. Socaciu; J. Med. Plant Res., 2011, 5, 2237-2244.

95.A. Pintea; D. Rugina; A. Bunea; R. Pop; C. Socaciu, J. Food Comp. Anal., 2011, 24, 830-836.

96.A. Chis; F. Fetea; H. Matei; C. Socaciu; Not. Bot. Horti. Agrobo., 2011, 39, 99104.

97.A. Pintea; D. Rugina; R. Pop; A. Bunea; C. Socaciu; H.A. Diehl; J. Ocular Pharmacol. \& Ther., 2011, 27, 315-321.

98.D. Rugină; Z. Sconţa; L. Leopold; A. Pintea; A. Bunea; C. Socaciu; J. Med. Food, 2012, 15, 700-706.

99.D.C. Vodnar; C. Socaciu; Chem. Central J., 2012, 61-69.

100. Bunea; D. Rugină; Z. Sconţa; R. M. Pop; A. Pintea; C. Socaciu; F.Tăbăran; C. Grootaert; K.Struijs; J. VanCamp; Phytochemistry, 2013, 95, 436-444.

101. C. Coman; L.F. Leopold; O.D. Rugină; L.Barbu-Tudoran; N. Leopold; M. Tofană; C. Socaciu; J. Nanopart. Res., 2013, 16, 2158-2167.

102. D.C. Vodnar; C. Socaciu; LWT-Food Sci.Technol., 2014, 57, 406-411.

103. D.Preda; I. Berindan Neagoe; O.Balacescu; $3^{\text {rd }}$ Int. Conf. on Polyphenols and Health, Kyoto, Japan, 2007.

104. Z. Diaconeasa; L. Leopold; D. Rugina; C. Socaciu; Int. J. Mol. Sci., 2015, 16, 2352-2365.

105. D. Rugină; Z. Diaconeasa; C. Coman; A. Bunea; C. Socaciu; A. Pintea; Oxidative Med. Cellular Longevity, 2015, 1-10.

106. F.V. Dulf; D.C. Vodnar; C. Socaciu; Food Chemistry, 2016, 209, 27-36.

107. Z. Diaconeasa; H. Ayvaz; D. Ruginǎ; L. Leopold; A. Stǎnilă; C. Socaciu; Plant Foods for Human Nutr., 2017, 72, 404-410.

108. C. Pop; A. M. Rotar; L. Salanţă; S. Socaci; F.Ranga; C. Socaciu;, Bull. USAMVFST, 2015, 72, 91-98.

109. M. Neacsu; C. Socaciu; M. Tamas; C. Blidar; Bull. USAMV-AGR, 2002, 58, 37-43.

110. M. Neacsu; S.Vicas; C. Socaciu; Bull. USAMV-AGR, 2008, 65, 310-315

111. V. Chedea; C. Echim; C. Socaciu; J. Food Biochem., 2011, 35, 92-108.

112. S. Zavoi; F. Fetea; F. Ranga; R. Pop; A. Baciu; C. Socaciu; Not. Bot. Horti. Agrobio., 2011, 39, 82-89. 
113. V.S. Chedea; P. Kefalas; C. Socaciu; Journal of Food Biochemistry, 2010, 34, $101-110$.

114. S. Vicas; D. Rugina; L. Leopold; A.Pintea A.; C. Socaciu; Not. Bot. Horti. Agrobio., 2011, 39, 48-57.

115. S.A. Socaci; C. Socaciu; C. Mureşan; A. Fărcaş; M.Tofană; S. Vicaş; A. Pintea; Phytochem. Anal., 2014, 25, 165-169.

116. S.A. Socaci; C. Socaciu; M. Tofana; V. Rati; A. Pintea; Phytochem. Anal., 2013, 24, 319-328.

117. S.I. Vicas; A.C.Teusdea; M. Carbunar; S. Socaci; C. Socaciu; Plant Foods Human Nutr., 2013, 68, 313-321.

118. R.M. Pop; Y. Weesepoel; C. Socaciu; A. Pintea; J.P. Vincken; H.Gruppen; Food Chemistry, 2014, 42, 1-8.

119. M. Badalica-Petrescu; S. Dragan; F. Ranga; F. Fetea; C. Socaciu; Not. Bot. Horti. Agrobio., 2014, 42, 9-18.

120. R. M. Pop; C. Socaciu; A. Pintea; A.D. Buzoianu; M.D. Sanders; H. Gruppen; J.P. Vincken; Phytochem. Anal., 2013, 24, 484-492.

121. R. M. Pop; A. Buzoianu; V. Rati; C. Socaciu; Not. Bot. Horti. Agrobio., 2014, 42, 545-550.

122. F.Bunghez; A. M. Rotar; D.C. Vodnar; G.M. Cătunescu; C. Socaciu; Rom. Biotechnol. Lett., 2016, 21, 1-15.

123. F.V. Dulf; D.C. Vodnar; E.H. Dulf; Z. Diaconeasa; C. Socaciu; LWT-Food Sci. Technol., 2018, 87, 241-249.

124. C.Socaciu; F.Ranga; F. Fetea; $5^{\text {th }}$ Int. Conf. on Plant Metabolomics Pacifico, Yokohama, Japan, 2008.

125. C. Moraru; K. Skjanes; D. Patras; C. Socaciu; C.J.J.Spetz; $18^{\text {th }}$ Int. Symposium on Carotenoids, Luzern, 9-14 July 2017.

126. A.G. Lazar; F.Romanciuc; M.A. Socaciu; C. Socaciu; Bull. USAMV-FST, 2015, 72, 103-115.

127. M. Andjelković; J. Van Camp; C. Socaciu; R. Verhe; Commun. Agric. Appl. Biol. Sci., 2006, 71, $19-23$.

128. C. Socaciu; F. Ranga; H. A. Diehl; Bull. USAMV-AGR, 2005, 61, 295-300.

129. M. Andjelkovic; J Van Camp; M. Pedra; K. Renders; C. Socaciu; R. Verhe; J. Agric. Food Chem., 2008, 56, 5181-5187.

130. F. Dulf; C. Socaciu; C. Bele; A. Pintea; M. Unguresan; Chem. Listy, 2008, 102, s265-s309.

131. M. Streza; D. Dadarlat; C. Socaciu; C. Bele; F. Dulf; V. Simon; Food Biophys., 2009, 4,147-150.

132. L.F. Leopold; H.A. Diehl; C. Socaciu; Bull. USAMV-AGR, 2006, 62, 288-293.

133. F. Dulf; M. Unguresan; D. Vodnar; C. Socaciu; Not. Bot. Horti. Agrobo., 2010, 38, 91-97.

134. L.F. Leopold; N. Leopold; H.A. Diehl; C. Socaciu; Spectroscopy-Int J., IOS Press, 2011, 112.

135. L.F. Leopold; N. Leopold; H.A. Diehl; C. Socaciu; Food Anal. Meth., 2012, 5, 405-407. 
136. T.E. Coldea; C. Socaciu; F. Fetea; F. Ranga; R.M. Pop; M. Florea; Not. Bot. Horti. Agrobio., 2013, 41, 143-149.

137. R. Banc; F. Loghin; D. Miere; F. Fetea; C. Socaciu; Not. Bot. Horti. Agrobio., 2014, 42, 556-564.

138. S. I. Vicas; A. C. Teusdea; M. Carbunar; C. Socaciu; Rom. Biotech. Lett., 2015, 20,1067-1075.

139. L. Cuibus; D. Dadarlat; M. Streza; F.V. Dulf; Z.Diaconeasa; C. Socaciu; J. Therm. Anal. Calorim., 2017, 127, 1193-1200.

140. L. Cuibus; R. Maggio; V. Mureșan; Z. Diaconeasa; O.L. Pop; C. Socaciu; Bull. USAMV-FST, 2015, 72, 70-76.

141. E. Mudura; T.E. Coldea; C. Socaciu; F. Ranga; C. Pop; A.M. Rotar; A. Pasqualone; J. Serbian Chem. Soc., 2018, 83, 19-30. 